\title{
European Commitment to COP21 and the Role of Energy Consumption, FDI, Trade and Economic Complexity in Sustaining Economic Growth
}

\author{
Buhari DOĞAN \\ Suleyman Demirel University, Turkey \\ doganbuhari@gmail.com \\ Daniel BALSALOBRE LORENTE ${ }^{1}$ \\ Department of Political Economy and Public Finance, Economic and Business Statistics and \\ Economic Policy \\ University of Castilla La Mancha, Cuenca, Spain \\ Daniel.Balsalobre@uclm.es \\ Muhammad Ali NASIR \\ Huddersfield Business School, University of Huddersfield, UK \\ m.a.nasir@hud.ac.uk
}

\begin{abstract}
The nexus between economic growth and energy consumption has been exhaustively explored, yet the empirical evidence and the theoretical points of view remain at odds. This study contextualises and capitalises on this discrepancy and examines the connection between non-renewable and renewable energy consumption and economic growth, considering the moderating impact of economic complexity, trade openness, FDI and institutional quality. We use a panel quantile regression model and data from 32 European countries in the period 1995-2014. Our key results show that economic complexity, renewable energy consumption, trade openness, FDI and institutional quality enhance economic growth. The results for non-renewable energy consumption showed both a positive and a negative impact in different quantiles, indicating that the consumption of renewable energy is in fact more effective for economic growth than the use of non-renewables. Our findings have far-reaching implications for stakeholders and policymakers working on sustainable economic growth and energy policy with a view to meeting the commitments made under the Paris Agreement (COP21).
\end{abstract}

Keywords: Renewable Energy. COP 21, Energy consumption, FDI, Institutional Quality, Complexity, Economic Growth, Trade.

JEL Codes: O13, P18, Q42, Q43,

\footnotetext{
${ }^{1}$ Corresponding author: Email daniel.balsalobre@uclm.es
} 


\section{1.- Introduction.}

After two decades of painstaking negotiations, in December 2015 several countries at the 21 st Conference of the Parties (COP21) in Paris reached a unanimous consensus whereby all the signatories would endeavour to tackle climate change and act to curb emissions of greenhouse gases (GHGs). It was agreed to limit global temperatures to $2^{\circ} \mathrm{C}$ above the pre-industrial era, to be achieved through joint action based on nationally determined contributions (NDCs). The Paris Agreement (COP21) encompasses a guide to policy measures to restrict the harmful impact of climate change. Although Kinley (2017) declared the COP (21) to be one of the most successful of all conferences on climate change as it redoubled the efforts to prevent its impact (Clémençon, 2016; Vandyck et al., 2016), some authors have expressed concerns that the agreement mainly addresses its economic effects (Muradov, 2014). It is therefore crucial to balance the desire to cut emissions as agreed under COP21 with the aim of achieving greater economic growth and development.

It is the goal of almost every nation to achieve sustainable economic growth. In this context, energy plays a key role as it is an essential ingredient in the production process. Energy consumption is a part of almost every economic activity and most social pursuits. The seminal study by Kraft and Kraft (1978) explored the connection between economic growth and energy usage, which is often manifested in four hypotheses: first, the growth hypothesis, which postulates that the use of energy produces economic growth (Kraft and Kraft, 1978; Bowden and Payne, 2009, 2010); second, the conservation hypothesis suggests that the consumption of energy is determined by economic growth (Abosedra and Baghestani, 1991); third, the feedback hypothesis highlights a bi-directional relationship between energy usage and economic growth (Fallahi, 2011; Shahbaz et al., 2020); and fourth, the neutrality hypothesis argues for a noncausal relationship (Soytas et al., 2007). While the four different hypotheses postulate different approaches to the link between energy consumption and income levels, they also disprove the 
notion of "one size fits all" and point out that for the sake of accuracy, the connection between energy consumption and economic growth must be viewed in a particular context and in the light of moderating factors. There is also an important ecological and environmental aspect, so the debate is often extended to renewable energy use and whether or not it contributes to economic growth in the same way. The evidence is contradictory, which keeps the debate alive (for instance, Ewing, 2007; Fang, 2011; Yildirim, 2012; Pao and Fu, 2013; Ocal and Aslan, 2013; Azlina et al., 2014; Tiwari, 2014; further discussion in the subsequent section). In addition to energy structure, urbanization and education are often linked to levels of development, and hence to underlying cause of economic disparity between countries (IMF, 2017). Among these structural factors, the sophistication of the economy as manifested in its complexity or complex production processes is a vital but somewhat underexplored factor that can be measured using the economic complexity index ${ }^{2}$ (hereafter ECI) to indicate a country's level of sophistication and production capabilities. This index determines the level of sustainable growth, human capital, institutional quality and innovation processes as measures of a country's complexity. In the last decade or so, the analysis of countries' economic complexity has attracted increasing interest and discussion, mainly because it offers a way to rank countries in the correct global order in terms of their competitiveness. Economic complexity is therefore used in analysis to determine the sophistication of the production process and the exchange of goods and services (Erkan and Y1ldırımc1, 2015), and is also important for determining the effects of international trade by measuring an economy's export diversity and complexity. More specifically, it analyses countries' export structure (Hidalgo and Hausmann, 2009). In this context, economic complexity (ECI) affects exports, which in turn impacts an economy's degree of trade openness (Lapatinas et al., 2019). Empirical evidence supports the notion that countries with high economic complexity tend to benefit more from trade. It also follows that countries that tend to

\footnotetext{
${ }^{2}$ A country's degree of complexity is measured through the Economic Complexity Index (ECI); see Hidalgo and Hausmann (2009) for details.
} 
benefit more from trade are likely to have higher trade openness (Carlin et al., 2001; Hausmann et al., 2007; Huchet-Bourdon et al., 2017).

Despite the importance of the nexus between an economy's complexity and its various aspects, this subject has so far received very little attention. Countries that have followed this course have often condoned energy consumption. For instance, some studies such as Hidalgo et al. (2007) have applied the export agenda analysis to forecast the form of diversification or the rate of economic growth (see Hidalgo and Hausmann, 2009; Agosin, 2009; Hausmann et al., 2014; Hartmann et al., 2016, 2017) while capturing a country's productivity and capabilities for exporting complex (i.e. high value-added) products. Specifically, economic complexity (ECI) influences the diversification of the export agenda and the rate of export of its technologyintensive products (Tacchella et al., 2013; Hausmann et al., 2014), and configures a country's level of diversification and productive structure (Gozgor, 2018). Some studies have also used the ECI to compare the trade competitiveness associated with the degree of R\&D in economies. The effects of R\&D processes can be considered an indicator of technical progress, which affects economic growth (Fang, 2011; Balsalobre et al., 2015; Hajko et al., 2018 ) and also reduces the costs of producing renewable energy (Stafforte and Tamberi, 2012). R\&D undoubtedly contributes to businesses' efficiency and competitiveness (Andersson et al., 2018), and the structural change caused by innovation creates new sectors that lead to sustained economic development (Saviotti and Pyka, 2004; Saviotti et al., 2016; Álvarez et al., 2017). High-level knowledge of various products offers more significant potential for economic and social development (Lin and Wang, 2015), and the sophistication and complexity of a country's economy are associated with its capacity to export high-tech outputs and its investment in R\&D development. R\&D delivers the knowledge necessary to obtain high-tech goods that generate new jobs and more efficient production processes (Saviotti and Pyka, 2004; 2013). This then begs the question of its possible implications for the relationship between an economy's energy 
consumption and its growth, and between economic growth and the consumption of renewable energy. However, current evidence does not offer many insights into this question, and our study aims to address this gap. As the evidence of economic complexity has focused on its implications for international trade (Hidalgo and Hausmann, 2009; Hausmann et al., 2007; Hesse, 2009), it makes sense to argue that in order to understand a country's complexity (Karras, 2003; Chang and Mendy, 2012; Rao and Rao, 2009), its trade openness must be explored in parallel with its energy consumption (Jalil and Feridun, 2014). Our study also contributes to the current body of knowledge by exploring this factor. Although a positive association can logically be assumed between the growth of an economy and the degree to which it openly trades, there is some evidence to suggest that trade openness does not have much impact on economic growth (see e.g. Babatunde, 2011 and Eris and Ulasan, 2013), while other authors argue that it is positively linked to tariffs (Yanikkaya, 2003). Edwards (1998) found a direct association between the rate of economic growth and trade restrictions, while other studies have found a negative association between economic growth and the degree to which an economy openly trades (Harission, 1996; Zanohogo, 2017; Adhikary, 2011). The birds-eye view of the relationship between an economy's trade openness and its growth rate reveals that it is complex and depends on contextual factors such as the degree of development and the size of the economy. These aspects, and contrasting evidence, provide a further rationale for the study subject. Nevertheless, not only trade openness, but foreign direct investment (FDI) and the quality of the institutions also play an important role in economic growth and development (Cadoret and Padovano, 2016; Dhrifi et al., 2019; Hayat, 2019; and Redmond and Nasir (2020). Therefore, we also look at the role of FDI and institutional quality.

Specifically in regard to the role of complexity, Álvarez et al. (2017) argued that the relevance of economic complexity in economic systems could be gauged by understanding the connection between energy consumption and economic growth, where innovation processes offer a new 
approach with applications and crucial implications for policymaking. Governments promote energy regulations to reduce their dependence on fossil fuel and its energy intensity. These actions may be influenced by the sophistication of several aspects such as the social, technical, economic or environmental features of energy systems, and their complex social and technological dynamics (Bale et al., 2015). This study therefore examines the impact of renewable sources and their connection with economic complexity (Yin et al., 2015; Chen et al., 2018; Yan et al., 2017; Shahbaz et al., 2017). In the last couple of decades, the share of renewable energy has significantly increased due to a range of factors, such as government regulation to promote the use of renewable energy (see Apergis and Payne, 2010), reduction in the cost of installing renewable energy production capacity (Bowden and Payne, 2010), oil price volatility (Apergis and Payne, 2012) and the positive effects of renewables in reducing carbon emissions (Sovacool and Brown, 2009). Innovation processes in the energy sector have also reduced environmental damage and the cost of implementing renewable sources (Álvarez et al., 2017). Economic complexity impacts human development by promoting structural change and specialised workforce training, raising consumer income and purchasing power and increasing the quality of the output of highly-skilled workers (Hartmann, 2014; Antonelli, 2016; Saviotti et al., 2016). Arguably, economic growth and development play an important role in enhancing quality of life and contributing to human development (Mariano and Rebelatto, 2014; Sen, 2001), although economic growth alone is not sufficient to understand human development processes. Hartmann (2014) concluded that a well-diversified economy is more important for human development than economic growth, since complexity improves the capacity to create higher education levels, health and infrastructures. The diversification of the economy and innovation must be prioritised to achieve higher levels of human development (Mustafa et al., 2017; Suri et al., 2011). This study therefore explores the moderating impact of economic complexity and sophistication on the link between energy consumption and economic growth, incorporating non-renewable and renewable forms of energy consumption. We also supplement the growth 
function with trade openness, FDI and institutional quality, which are crucial factors to bear in mind, particularly considering the openness of contemporary economies and the influence of international trade, FDI and institutional quality on growth and development. We propose an empirical model based on the energy consumption-growth nexus hypothesis that connects economic growth with economic complexity, non-renewable and renewable energy consumption, trade openness, FDI and institutional quality. We assume that economic growth is contingent on ECI energy use, trade openness, FDI and the institutional quality of the underlying economy, using a panel quantile-regression model and data on 32 European economies from 1995 to 2014. Our key findings are that renewable energy consumption, economic complexity, trade openness, FDI and institutional quality are crucial for enhancing economic growth. The results for non-renewable energy use had both a positive and negative outcome in different quantiles, suggesting that renewable energy consumption is more suitable than non-renewable energy. Our findings have far-reaching implications for stakeholders and policymakers focused on sustainable economic growth and energy policy, and particularly on balancing economic growth and meeting the COP21 commitments.

The rest of the paper continues as follows: $\S 2$ considers the current evidence on the subject; $\S$ 3 describes the methodology and data; the analysis and findings are presented in $\S 4$; and the conclusion and policy implications in $\S 5$.

\section{2.- Literature review.}

In the context of the debate on maintaining economic growth and environmental sustainability post-COP21, the study analyses the six nexuses of economic growth: the economic complexitygrowth nexus, the energy consumption-growth nexus, the renewable energy consumptiongrowth nexus, the trade openness-growth nexus, the FDI-growth nexus and the institutional quality-growth nexus. 
The first aspect of the study is the role played by energy consumption in enhancing economic growth. Since the seminal work by Kraft and Kraft (1978), numerous studies have explored the link between energy usage and economic growth. Theoretically, this nexus can be explained in the light of four hypotheses: first, the growth hypothesis, according to which economic growth can be enhanced by increasing energy consumption (Kraft and Kraft, 1978; Bowden and Payne, 2009, 2010); second, the conservation hypothesis, which holds that economic growth causes energy consumption (Abosedra and Baghestani, 1991); third, the feedback hypothesis, highlighting a bidirectional connection between economic growth and energy usage (Fallahi, 2011); and fourth, the neutrality hypothesis, according to which there is no causal connection between variables (Soytas et al., 2007). The studies on the subject have overarchingly supported one of the four hypotheses. To reiterate, the study contributes to the energy-growth nexus hypothesis by extending this framework to include economic complexity and other explanatory factors. Current studies on renewable energy consumption and economic growth often categorise this nexus in the light of four hypotheses. For instance, Ewing et al. (2007) found a positive connection between renewable energy usage and economic growth, thus providing support for the growth hypothesis. Similarly, a later study by Fang (2011) on China reported unidirectional causation from renewable energy consumption to growth. However, analytical studies by Ocal and Aslan (2013) on Turkey and Azlina et al. (2014) on Malaysia found unidirectional causation running in the opposite direction i.e., from growth to renewable energy use, hence validating the conservation hypothesis. An empirical study by Tiwari (2014) on USA and Pao and $\mathrm{Fu}$ (2013) on Brazil showed the presence of bidirectional causation between growth and renewable energy consumption, confirming the feedback hypothesis. Other studies have also reported the lack of statistically significant evidence for causation between growth and renewable energy use (see Payne, 2009; Yildirim, 2012). 
Economic structure and energy efficiency determine energy consumption and - by extension emissions, which implies that these are essential driving forces of sustainable development. Specifically, developed countries have advanced energy consumption structures (Hu et al., 2018) embedded in their economic make-up, so productivity is strongly related to them (Feng et al., 2009; Zhang and Song, 2015; Chunbo, 2008). Saygin et al. (2015) showed that a high proportion of renewables in the total energy mix ensures better energy security and lower carbon emissions, and has positive effects on human health. In line with this view, it is indispensable to extend the use of renewables and more efficient infrastructures to stimulate low-emission electricity systems (Mutoh, 2006; Dogan, et al., 2020). Access to high-tech would improve the consistency of a more secure and efficient system (Fang, 2012). Some studies on the connection between energy usage and economic complexity (ECI) highlight that the reduction in emissions is a consequence of promoting clean technologies and energy innovation processes (Can and Gozgor, 2017; Dogan et al. 2019), while others argue that the positive effects of economic complexity (Sen, 2001) are overshadowed by the negative (Myrdal, 1957; Schwartz, 2004), and that economic diversification alone does not inevitably lead to human well-being. In this context, this study refreshes the previous literature and offers new insight into the significance of economic complexity (ECI), coupled with the additional driving forces of energy use, trade openness, FDI and institutional quality. Economic complexity is often associated with the capacity to quantify the productive structure of a country (Bustos et al., 2016; Hausmann and Klinger, 2006; Hausmann et al., 2014; Hidalgo et al., 2007; Hidalgo and Hausmann, 2009; Tacchella et al., 2013, among others). The growing body of literature on the subject identifies a positive link between income per capita and economic complexity (Hidalgo et al., 2007; Hidalgo and Hausmann, 2009), where economic growth and development are seen as an approach that renews the productive structure and promotes structural changes and economic diversification (Rosenstein-Rodan, 1943; Rostow, 1959, 1990; Hidalgo et al., 2007; Klinger 
and Lederman, 2006). Complex economic systems require a range of capabilities to adapt to technological change by fostering innovation, competitiveness and economic diversity to modernize economic structures.

Our paper mainly analyses the effects of economic complexity (ECI) to measure the capacity and efficiency for exporting highly complex and high value-added products on economic growth (Can and Gozgor, 2017; Gozgor, 2018). The ECI indicator reveals the status of economic development (Eagle et al., 2010; Gao and Zhou, 2016), and hence the growth and technical progress connected to an economy's capabilities. This evidence has been previously validated (Hidalgo and Hausmann, 2009), and a positive connection has also been found between ECI and economic growth (Gozgor, 2018) deriving from the type and level of institutional quality, the shape of knowledge accumulation, physical capital, the quality of exports or the labour force (Hausmann et al., 2011; Gozgor, 2018). Its production features are the result of a country's level of sophistication and skill-based labour production and capture the knowledge of a country's production (Hidalgo et al., 2007; Hidalgo and Hausmann, 2009). In other words, complexity defines the productive structure of an economy and its ability to generate high-tech output (Hausmann et al., 2014). Ferrarini and Scaramozzino (2016) conclude that the high income of developed countries is the reason they produce more complex outputs from a broader set of inputs and industries.

In line with the previous literature, we also assume that its productive structures determine an economy's institutional quality and social capital (Hidalgo, 2015). Although economic growth has traditionally been perceived as a panacea for development, we consider this process to be more complex (UNDP, 2000). For instance, Shahbaz et al. (2019) studied the association between life expectancy and income in several sub-Saharan countries, while Sen (1998) concluded that economies with lower income levels had a higher life expectancy than highincome economies. Some of the empirical evidence therefore disproves the notion that 
economic growth guarantees quality of life, as human development is enhanced by the quality of economic growth and the ability to solve social and development problems (Sen, 1981). In other words, economic growth cannot be directly inferred as human development and improvement in the quality of life (Sachs, 2004); whereas the true spirit of development incorporates both social and economic aspects to encourage freedoms and institutional quality (Sen, 2001). In terms of the socio-economic significance of complexity and knowledge, there is an argument that the development of an economy can be influenced by complexity. A study by Hartmann et al. (2017) reported a close connection between economic complexity, income inequality, education and income levels. Ferrarini and Scaramozzino (2016) examined how economic complexity affects economic development and the formation of human capital. Lee (2016a, 2016b) and Mustafa et al. (2017) concluded that some Asian countries have enhanced their economic complexity systems by investing in human capital and technological innovations.

The economic complexity and sophistication that leads to competitiveness has implications for international trade (Erkan and Kaya, 2015). It confers an advantage in global competitiveness by increasing the production and export of high-value goods, where R\&D plays an important part in the manufacturing process and exports. In other words, economic sophistication allows countries to create productive networks in the manufacturing and advanced service sectors, with ascending returns to scale (Gala et al., 2017). Conversely, when countries have low diversification, it can be assumed that the products they export are of a lower technological grade (Tacchella et al., 2013; Gala, 2017) and that they have limited knowledge and technology available (Hausmann et al., 2014). As their ability to generate complex goods increases, so does the likelihood of a relatively high yield compared to less able countries (Tacchella et al., 2013). Commodity-dependent countries do not encourage investment in commercial goods and services due to macroeconomic and real exchange-rate volatility caused by unpredictable 
commodity prices (Ferrarini and Scaramozzino, 2016; Nkurunziza et al., 2017). In their study, Hidalgo and Hausmann (2009) assumed that labour and capital are insufficient to produce goods and that knowledge is a key factor in production, so countries need to adopt special infrastructures, skilled labour, property rights and regulations in order to produce high-tech goods. Hausmann et al. (2014) concluded that complex economies produce information through a network of people who create a broad array of knowledge-intensive products, while lowcomplex economies produce a smaller variety of products with a narrow productive knowledge base requiring less information. The inclusion in the study of ECI in conjunction with the other explanatory factors is therefore a rational choice.

Our work links trade openness not only to energy consumption and complexity but to economic growth. Here, the Ricardian trade model sees differences in technological progress as being the core reason for countries to engage in trade (Krugman, 1987), while the Heckscher-Ohlin framework considers the key to lie in differences in the factor endowments. For instance, Ahmed and Sattar (2004) concluded that international trade underpins development in labourintensive export business. In another noteworthy study, Romer (1990) held that unrestricted participation in global trade enhances the growth of an economy. In terms of internal growth, technology transfer is one example of how a trade deficit affects economic growth (Karras, 2003). Following the internal growth theory, Adhikary (2011) concluded that a foreign trade deficit would affect economic growth by permitting foreign investment to be redirected to more efficient sectors. According to this theory, Constant and Yaoxing (2010) concluded that an open economy tends to increase its expertise and division of labour, with positive effects on productivity and export capability. This evidence also confirms that trade openness plays a crucial part in enhancing economic growth. Adhikary (2011) concluded that most trade openness accelerates capital and technology transfers, which enables the application of innovations due to more efficient trading partners, and rising economic growth (Karras, 2003). 
Finally, there is also a strand of literature that suggests that FDI and institutional quality play an important role in economic growth. Drawing on the empirical work by Cadoret and Padovano (2016), Dhrifi et al. (2019), Hayat (2019) and most recently Redmond and Nasir (2020), we have also considered the role of FDI and institutional quality in our analysis. It is worth noting that the inclusion of these explanatory factors together with energy consumption and complexity will yield more robust results by addressing the issue of omitted variable bias in the model.

\section{3.- Methodology}

We model economic growth measures in terms of Gross Domestic Product (GDP) as a function of its explanatory variables in the following:

$$
\begin{gathered}
G D P_{2, i t}=f\left(E C I_{i, t}^{\beta_{1}}, R E C_{i, t}^{\beta_{2}}, N R E C_{i, t}^{\beta_{3}}, O P_{i, t}^{\beta_{4}}, F D I_{i, t}^{\beta_{5}}, I N S T_{i, t}^{\beta_{6}}\right)+\mu_{i, t} \\
G D P_{2, i t}=\beta_{0}+\beta_{1} E C I_{i, t}+\beta_{2} R E C_{i, t}+\beta_{3} N R E C_{i, t}+\beta_{4} O P_{i, t}+\beta_{5} F D I_{i, t}+\beta_{6} I N S T_{i, t}+\mu_{i, t}
\end{gathered}
$$

where $i$ stands for the underlying economy, $t$ is the time, GDP is the income level per capita, ECI refers to the economic complexity index, REC is the share of renewable energy and NREC is the share of non-renewable energy out of total energy consumption, OP is per capita trade openness, FDI is foreign direct inflows and INST represents the quality of the institutions measured by the widely used Law and Order indicator. Lastly, $\mu$ represents the error term.

The expectation is that $\beta_{1}>0, \beta_{2}>0, \beta_{3}>0$ and $\beta_{4}>0$, and that the impact of economic complexity will be positive $\left(\beta_{1}>0\right)$. This is because economic complexity can be associated with increased productivity and human capital. It is also expected that $\beta_{2}>0$ and $\beta_{3}>0$, as both non-renewable and renewable forms of energy consumption, will have a positive effect on economic growth. According to the current evidence on the subject, renewable energy generation and consumption requires a higher level of technological advancement. Trade openness can also be expected to have a positive impact $\left(\beta_{4}>0\right)$. We assume trade openness to be positive because European countries are developed and have a significant proportion of high value-added and industrial 
products in their exports. Foreign direct investment and institutional quality can be expected to have a positive effect: $\left(\beta_{5}>0\right)$ and $\left(\beta_{6}>0\right)$ respectively. Lastly, if robust inferences are to be drawn, it is also vital that our explanatory variables should produce statistically significant coefficients or associations with economic growth.

\section{1.- Panel quantile regression.}

The first stage of our analysis consists of pairwise correlation tests to determine whether the variables are correlated, but mainly to uncover any multicollinearity problems. As can be seen in Table 1, there are no additional concerns regarding multicollinearity issues. We then apply the cross-section dependence test. For the pooled OLS estimation, we compare the standard error estimates before applying panel quantile regression. Pooled OLS can be used to derive unbiased and consistent estimates of parameters even when time-constant attributes are present (Hoechle, 2007). It is preferred to apply the panel quantile approach to examine the impacts of the factors affecting economic growth, as the ordinary least squares (OLS) regression can overestimate their effects. OLS could also fail to take account of the heterogeneous distribution. Nonetheless, the panel quantile provides more powerful estimations against OLS if the errors do not follow a normal distribution (Apergis et al., 2018). We therefore use this approach to investigate the association between economic growth and the underlying variables.

Following Altunbaş and Thornton (2019) and Zheng et al. (2019), we use panel quantile regression methodology to account for the likelihood of heterogeneity and estimate the distribution of conditional economic growth (GDP per capita) in different amounts (Canay, 2011; Galvao, 2011).

We specify the $\tau^{\text {th }}$ quantile $(0<\tau<1)$ of the conditional distribution of the response variable, given a set of explanatory factors $X_{i, t}$ :

$$
Q_{\tau}\left(\frac{G D P_{, i t}}{X_{i, t}}\right)=\alpha_{\tau}+\beta_{\tau} X_{i, t}+\alpha_{\tau} \mu_{i, t}
$$


where $X_{i, t}$ represents the logged independent variables $(E C I, R E N, N R E N, O P)$ and $\mu_{i, t}$ indicates the unobserved element. The coefficients are estimated while the residuals are minimised (Koenker, 2004):

$$
\left(Q_{\tau}\left(\beta_{\tau}\right)=\min _{\beta} \sum_{i=1}^{n}\left[\left|\ln H_{i, t}-\beta_{\tau} X_{i, t}\right|\right]\right)
$$

We first use a panel quantile framework incorporating fixed effects following the approach taken by Canay (2011), and an improved quantile panel data prediction method suggested by Powell (2016). The generalized distribution regression estimator developed by Powell (2016) concentrates on the main problem with conventional distribution estimators, namely the inclusion of additional variables that change the interpretation of the estimated coefficients. The novelty of this framework is that even in the presence of additional control variables, it creates unconditional quantile treatment effects, allowing for endogeneity and the inclusion of additional instruments and "proneness" variables (Powell, 2016). Quantile estimation enables the impact of the covariates to vary with the disturbance term, which is nonseparable. Panel data approaches in the literature include a fixed-effect term which changes the explanation of the variables for cross-sectional quantile regressions (Canay, 2011), as it breaks down the disturbance term and assumes that the variables remain the same based on the fixed effects. We therefore follow Powell's (2016) approach for quantile regression, which uses nonadditive fixed effects. For identification purposes, the regression approach accounts for withingroup variation, while maintaining the property of non-separable disturbance (in general, it motivates the use of quantile estimators). The resulting estimates can be interpreted in a similar manner with the cross-sectional quantile estimates. The parameter values show the effects of independent variables in the resulting $\tau^{\text {th }}$ quantile of distribution. Powell's quantile regression approach (2016) also uses the panel data feature required to estimate the effects of quantile 
treatment. We have no opportunity to predict the constant effect, and the estimates of the parameters are consistent for small $T$ (Baker, 2016).

\section{2.- Data.}

We explore the effects of economic complexity, non-renewable and renewable energy consumption, trade openness, FDI and institutional quality on economic growth in 32 European economies from 1995 to 2014: United Kingdom, Switzerland, Norway, Belgium, Iceland, Bulgaria, Sweden, Czech Republic, Finland, Slovakia, Slovenia, Romania, Portugal, Poland, Austria, Netherland, Malta, Hungary, Luxemburg, Lithuania, Latvia, Cyprus, Italy, Croatia, Spain, Greece, Ireland, Estonia, Germany, Denmark, Macedonia and France. We use the following proxies to measure the variables: economic growth is measured as GDP per capita (constant 2010); renewable and non-renewable energy consumption is measured in million tonnes of oil equivalent; trade openness is measured as the ratio of total trade (including exports and imports) as a proportion of GDP; foreign direct investment is foreign direct inflows (\$ USD); institutional quality is measured by the widely used law and order indicator; and the economic complexity index (ECI) is applied to measure economic complexity, with data on ECI from the Atlas Media database (2018). A higher value of ECI indicates greater economic complexity. For the institutional quality indicator, the dataset used in this study is taken from the International Country Risk Guide (ICRG) and converted into natural logs to avoid problems with the distribution equation of the data series. Apart from the ECI and INST, the data on other variables are taken from the World Bank's World Development Indicators database (WDI, 2019).

\section{4.- Analysis and Empirical Findings.}


We started the analysis with a pairwise correlation test to assess the possibility of multicollinearity problems. As seen in Table 1, there are no serious concerns regarding multicollinearity.

Table 1: Pairwise correlation results

\begin{tabular}{lrrrcccc}
\hline & ECI & GDP & REN & NREN & OP & FDI & INST \\
\hline ECI & 1.000 & & & & & & \\
GDP & -0.346 & 1.000 & & & & & \\
REN & 0.850 & -0.156 & 1.000 & & & & \\
NREN & 0.560 & -0.078 & 0.454 & 1.000 & & & \\
OP & -0.412 & 0.239 & -0.267 & -0.054 & 1.000 & & \\
FDI & -0.327 & -0.311 & 0.103 & -0.566 & -0.678 & 1.000 & \\
INST & 0.570 & -0.789 & 0.089 & 0.521 & 0.560 & 0.560 & 1.000 \\
\hline
\end{tabular}

Notes: The dependent variable is GDP. ECI refers to economic complexity, REN to renewable energy, NREN to non-renewable energy, OP to trade openness, FDI to foreign direct investment and INST to institutional quality.

Table 2 contains a summary of descriptive statistics. Income per capita had the highest mean followed by FDI, whereas the highest standard deviation is in GDP, and the secondhighest standard deviation value is in economic complexity (ECI). The mean and standard deviation values show the central tendency and variability of these variables.

Table 2: Summary statistics

\begin{tabular}{lccccccc}
\hline \multicolumn{1}{c}{} & ECI & GDP & REN & NREN & OP & FDI & INST \\
\hline Mean & 5.934 & 30.566 & 3.988 & 5.089 & 7.804 & 13.980 & 4.566 \\
Median & 13.733 & 27.930 & 3.067 & 4.340 & 6.765 & 9.235 & 3.470 \\
Maximum & 5.340 & 34.780 & 7.945 & 21.780 & 18.678 & 34.210 & 1.987 \\
Minimum & -3.180 & 17.900 & 3.120 & 0.852 & 2.656 & -1.657 & -1.870 \\
Std. Dev. & 1.779 & 2.659 & 1.379 & 1.338 & 0.785 & 1.045 & 0.930 \\
Skewness & -0.133 & 0.759 & -0.997 & 1.249 & 0.906 & 1.033 & 0.455 \\
Kurtosis & 1.854 & 3.070 & 3.485 & 4.385 & 2.970 & 2.498 & 1.208 \\
Jarque-Bera & 3.675 & 56.20 & 1.021 & 199.184 & 8.046 & 1.344 & 0.560 \\
Probability & 0.000 & 0.000 & 0.000 & 0.000 & 0.000 & 0.000 & 0.000 \\
Observations & 823 & 823 & 823 & 823 & 823 & 823 & 823 \\
\hline Notes: The dependent variable is GDP. ECI refers to economic complexity, REN to renewable energy, NREN \\
to non-renewable energy, OP to trade openness, FDI to foreign direct investment and INST to institutional \\
quality.
\end{tabular}

As there can be serious consequences of cross-sectional dependence in the estimations, we performed cross-sectional dependence tests, and the results are shown in Table 3. These include the LM test by Breusch-Pagan (1980), the Pesaran (2004) scaled LM tests, and the Pesaran CD and Baltagi et al. (2012) bias-corrected scaled LM test. 
Table 3: Cross-section dependence tests

\begin{tabular}{|c|c|c|c|c|c|c|c|}
\hline & ECI & GDP & REN & NREN & OP & FDI & INST \\
\hline $\begin{array}{l}\text { Breusch-Pagan } \\
\text { LM }\end{array}$ & $5.120 * * *$ & $11.780 * * *$ & $10.098 * * *$ & $2.049 * * *$ & $3.677 * * *$ & $1.022 * * *$ & NA \\
\hline $\begin{array}{l}\text { Pesaran scaled } \\
\text { LM }\end{array}$ & $1.320 * * *$ & $21.467 * * *$ & $9.452 * * *$ & $2.389 * * *$ & $4.761 * * *$ & $2.038 * * *$ & NA \\
\hline $\begin{array}{l}\text { Bias-corrected } \\
\text { scaled LM }\end{array}$ & $7.340 * * *$ & $10.332 * * *$ & $13.677 * * *$ & $2.204 * * *$ & $7.012 * * *$ & $4.980 * * *$ & NA \\
\hline Pesaran CD & $1.102 * * *$ & $-2.405^{* * *}$ & $14.890 * * *$ & $2.266 * * *$ & $3.023 * * *$ & $6.090 * * *$ & NA \\
\hline
\end{tabular}

Disturbances in a panel framework are traditionally accepted to be cross-sectionally independent. The four cross-sectional dependence tests in Table 3 suggest there is no issue of cross-sectional dependence, which is a positive outcome as it can yield biased estimates and lead to serious errors in predictions. Panel unit root tests were also performed, and the results show that considering variables in the log form ensures data stability (these results can be provided on request).

Table 4: Standard Error Estimations: Pooled OLS

\begin{tabular}{|c|c|c|c|c|c|}
\hline & OLS & White & Rogers & Newey-West & $\begin{array}{c}\text { Driscoll } \\
\text { Kraay }\end{array}$ \\
\hline \multirow[t]{2}{*}{ ECI } & $0.000 * * *$ & $0.000 * * *$ & $0.000 * * *$ & $0.000 * *$ & $0.000 * *$ \\
\hline & $\begin{array}{l}{[1.789]} \\
(0.445)\end{array}$ & $\begin{array}{l}{[2.896]} \\
(0.367)\end{array}$ & $\begin{array}{l}{[3.054]} \\
(0.055)\end{array}$ & $\begin{array}{l}{[3.987]} \\
(0.766)\end{array}$ & $\begin{array}{l}{[2.811]} \\
(0.045)\end{array}$ \\
\hline \multirow[t]{2}{*}{ REN } & $0.056 * *$ & $0.056 * * *$ & $0.056 * * *$ & $0.056 * * *$ & $0.056 * * *$ \\
\hline & $\begin{array}{l}{[2.489]} \\
(1.005)\end{array}$ & $\begin{array}{l}{[2.217]} \\
(0.905)\end{array}$ & $\begin{array}{l}{[1.870]} \\
(0.970)\end{array}$ & $\begin{array}{l}{[4.099]} \\
(1.933)\end{array}$ & $\begin{array}{l}{[2.760]} \\
(0.688)\end{array}$ \\
\hline \multirow[t]{2}{*}{ NREN } & $0.064 * * *$ & $0.064 * *$ & $0.064 *$ & $0.064 * * *$ & 0.064 \\
\hline & $\begin{array}{l}{[1.793]} \\
(0.453)\end{array}$ & $\begin{array}{l}{[1.150]} \\
(0.898)\end{array}$ & $\begin{array}{l}{[1.770]} \\
(1.043)\end{array}$ & $\begin{array}{l}{[1.231]} \\
(1.453)\end{array}$ & $\begin{array}{l}{[1.909]} \\
(1.006)\end{array}$ \\
\hline \multirow[t]{2}{*}{ OP } & $0.146^{* *}$ & $0.146^{* * *}$ & $0.146 * * *$ & $0.146^{* * *}$ & $0.146 * * *$ \\
\hline & $\begin{array}{c}{[2.104]} \\
(1.566) \\
0.053 * *\end{array}$ & $\begin{array}{c}{[5.890]} \\
(0.220) \\
0.053 * *\end{array}$ & $\begin{array}{c}{[3.067]} \\
(1.480) \\
0.053 * * *\end{array}$ & $\begin{array}{c}{[3.970]} \\
(1.503) \\
0.053 * * *\end{array}$ & $\begin{array}{c}{[3.806]} \\
(0.206) \\
0.053 * * *\end{array}$ \\
\hline FDI & $\begin{array}{l}{[1.404]} \\
(2.098)\end{array}$ & $\begin{array}{l}{[4.010]} \\
(0.784)\end{array}$ & $\begin{array}{l}{[2.340]} \\
(1.986)\end{array}$ & $\begin{array}{l}{[3.023]} \\
(1.878)\end{array}$ & $\begin{array}{l}{[2.056]} \\
(3.055)\end{array}$ \\
\hline \multirow[t]{2}{*}{ INST } & $0.053 * *$ & $0.053 * * *$ & $0.053 * * *$ & $0.053 * * *$ & $0.053 * * *$ \\
\hline & $\begin{array}{c}{[1.404]} \\
(0.959) \\
0.003 * *\end{array}$ & $\begin{array}{c}{[4.010]} \\
(0.090) \\
0.003 * * *\end{array}$ & $\begin{array}{c}{[2.340]} \\
(1.354) \\
0.003 * * *\end{array}$ & $\begin{array}{c}{[3.023]} \\
(0.060) \\
0.003 * *\end{array}$ & $\begin{array}{c}{[2.056]} \\
(1.008) \\
0.003 * * *\end{array}$ \\
\hline Constant & $\begin{array}{c}{[1.809]} \\
(0.889) \\
640\end{array}$ & $\begin{array}{c}{[1.034]} \\
(0.750) \\
640\end{array}$ & $\begin{array}{c}{[1.561]} \\
(0.970) \\
640\end{array}$ & $\begin{array}{c}{[2.280]} \\
(1.231) \\
640\end{array}$ & $\begin{array}{c}{[2.056]} \\
(1.077) \\
640\end{array}$ \\
\hline $\mathrm{R}^{2}$ & 0.346 & 0.346 & 0.346 & 0.346 & 0.346 \\
\hline
\end{tabular}




\begin{abstract}
Notes: (1) ***, ** and * represent significance at the 1\%, 5\% and $10 \%$ level respectively. The dependent variable is GDP. ECI refers to economic complexity, REN to renewable energy, NREN to non-renewable energy, OP to trade openness, FDI to foreign direct investment and INST to intuitional quality.(2) The t-statistics (in brackets) are based on estimates of standard error obtained from the covariance matrix estimators in the column headings. (3) The numbers in parentheses in the third line of each variable indicate the coefficient.
\end{abstract}

Table 4 presents and summarises the standard-error estimates for the pooled OLS estimation by using five approaches and considering the full sample; the findings are shown in Table 4. All the results are significant for renewable and non-renewable energy consumption, economic complexity, trade, foreign direct investment, and institutional quality and the constant term. Tstatistics are significant for the pooled OLS estimation with Driscoll-Kraay, Newey-West, Rogers and White standard errors respectively. When the pooled OLS estimation results are significant, we apply the panel quantile regressions to the overall sample and consider the fixed effects in the panel data. Tables 5 to 7 show the results of our estimation with the quantile regression approach (Canay, 2011; Powell, 2015; 2016) for the full sample.

The results of the quantile regression analysis reveal that economic complexity (ECI) has a positive impact on GDP and enhances growth in the underlying countries. The results are also robust at the different quantiles and have a significance level of $1 \%$, and at different model specifications (Tables 5, 6 and 7). The fact that ECI has a major impact on GDP - and greater than the role of trade openness - suggests that countries should focus on long-term strategies to enhance innovation in goods and services. The positive effects of economic complexity (ECI) on GDP confirm the findings of prior studies such as Hidalgo and Hausmann (2009), Agosin (2009), Hartmann (2014), Hausmann et al. (2014), and Hartmann et al. (2016, 2017) when capturing productivity and capabilities for exporting complex (high value-added) products. They argue that economic complexity (ECI) plays an important part in the diversification of exports and the export of high-tech products (Hausmann et al., 2014; Tacchella et al., 2013), and determines an economy's degree of diversification and productive structure (Gozgor, 
2018). Our findings provide further evidence and confirm that economic complexity enhances economic growth in the underlying European economies.

The panel quantile regression results indicate that renewable energy consumption (REN) tends to affect economic growth significantly and positively (Tables 5, 6 and 7). These results add to the current evidence on the subject. Specifically, our findings are in line with Ewing (2007) on USA, Fang (2011) on China, Tiwari (2014) on USA and Pao and Fu (2013) on Brazil, although they disagree with Ocal and Aslan (2013) on Turkey, Azlina et al. (2014) on Malaysia, and Payne (2009) and Yildirim (2012) on USA, who found no causal effect of renewable energy on growth. However, our empirical results indicate that the consumption of renewable energy enhances economic growth in the underlying European economies.

Interestingly, the analysis of non-renewable energy consumption showed less promising results for growth than renewable energy consumption. The non-renewable consumption coefficients had both positive and negative statistically significant signs in some quantiles (Table 5, 6 and 7). For example, for the first model in Table 5, non-renewable energy consumption (NREN) has a positive impact in the $1^{\text {st }}, 2^{\text {nd }}, 4^{\text {th }}$ and $10^{\text {th }}$ quantiles but a negative impact in the $1^{\text {st }}, 3^{\text {rd }}$ and $7^{\text {th }}$ quantiles. This is also the case in the results in Tables 5 and 6 , where non-renewable energy consumption (NREN) has a positive impact in the $1^{\text {st }}, 4^{\text {th }}, 7^{\text {th }}$ and $10^{\text {th }}$ quantiles but a negative impact in the $2^{\text {nd }}, 6^{\text {th }}, 8^{\text {th }}$ and $9^{\text {th }}$ quantiles. Non-renewable energy consumption (NREN) has a positive impact in the $3^{\text {rd }}, 5^{\text {th }}, 6^{\text {th }}$ and $7^{\text {th }}$ quantiles, and a negative sign in the $1^{\text {st }}, 2^{\text {nd }}, 4^{\text {th }}$ and $9^{\text {th }}$ quantiles. The positive coefficients support the growth hypothesis and confirm the empirical results, in line with previous empirical evidence from Kraft and Kraft (1978), Bowden and Payne (2009, 2010) and Fallahi (2011). The findings are contrary to studies such as that of Soytas et al. (2007), which found no association and supported the neutrality hypothesis. The presence of positive and negative coefficients in different quantiles offers further insight into the underlying economies, although these contrasting results also suggest 
that these countries use non-renewable energy sources inefficiently. The main reason for the negative signs may be that the country directs its energy consumption to inefficient sectors. The upside of the less promising results of non-renewable compared to renewable energy in terms of economic growth is that the consumption of renewables is more useful for achieving sustainable growth.

Finally, the results highlight a positive and statistically significant impact of trade, FDI and institutional quality on growth in all quantile levels (Tables 5, 6 and 7). This is to be expected, as a positive association is often found between trade openness, FDI and institutional quality and economic growth. Nonetheless, our findings contribute to and contradict the studies that suggest that trade openness does not exert any direct impact on economic growth (Eris and Ulasan, 2013; Babatunde, 2011) or argue that trade tariffs and taxes are positively associated with economic growth (Yanikkaya, 2003).

The findings presented in this study are statistically very significant, and contradict the results of Edwards (1998), who suggested a weak association between trade restraint and economic growth. They also ruled out the notion of a negative link between trade openness and economic growth (Harission 1996; Zanohogo, 2017; Adhikary, 2011). Our results are intuitive, as trade openness benefits countries in several ways; for instance, transfer for production occurs through international trade, which enables countries to increase production. Trade openness also ensures that the products manufactured are more sophisticated and complex.

Table 5: Canay (2011) fixed effect estimators' model

\begin{tabular}{|c|c|c|c|c|c|c|c|c|}
\hline & (1) & (2) & (3) & (4) & (5) & (6) & (7) & (8) \\
\hline VARIABLES & 0.05 & 0.1 & 0.2 & 0.3 & 0.4 & 0.5 & 0.6 & 0.7 \\
\hline ECI & $\begin{array}{c}0.467 * * * \\
(0.356)\end{array}$ & $\begin{array}{c}0.500 * * * \\
(0.780)\end{array}$ & $\begin{array}{c}0.345 * * \\
(0.671)\end{array}$ & $\begin{array}{c}0.677 * * \\
(0.098)\end{array}$ & $\begin{array}{c}0.986 * * * \\
(0561)\end{array}$ & $\begin{array}{c}0.568 * * * \\
(0.792)\end{array}$ & $\begin{array}{c}0.089 * * * \\
(0.606)\end{array}$ & $\begin{array}{r}0.056 * * \\
(1.044)\end{array}$ \\
\hline REN & $\begin{array}{c}0.454 * * * \\
(0.052)\end{array}$ & $\begin{array}{c}0.108 * * * \\
(0.094)\end{array}$ & $\begin{array}{c}0.190 * * * \\
(0.121)\end{array}$ & $\begin{array}{c}0.342 * * * \\
(0.416)\end{array}$ & $\begin{array}{c}0.187 * * * \\
(0.013)\end{array}$ & $\begin{array}{c}0.433 * * * \\
(0.043)\end{array}$ & $\begin{array}{c}0.463 * * * \\
(0.050)\end{array}$ & $\begin{array}{r}0.339 * * \\
(0.021)\end{array}$ \\
\hline NREN & $\begin{array}{c}-0.112 * * * \\
(0.331)\end{array}$ & $\begin{array}{c}-0.079 * * * \\
(0.401)\end{array}$ & $\begin{array}{c}-0.080 * * * \\
(0.065)\end{array}$ & $\begin{array}{c}0.027 * * * \\
(0.144)\end{array}$ & $\begin{array}{c}0.043^{* * *} * \\
(0.067)\end{array}$ & $\begin{array}{c}0.078 * * * \\
(0.037)\end{array}$ & $\begin{array}{c}-0.162 * * * \\
(0.134)\end{array}$ & $\begin{array}{c}0.091 * * \\
(0.239)\end{array}$ \\
\hline OP & $\begin{array}{c}0.061 * * * \\
(0.042)\end{array}$ & $\begin{array}{c}0.187 * * * \\
(0.443)\end{array}$ & $\begin{array}{c}0.648 * * * \\
(0.781)\end{array}$ & $\begin{array}{c}0.154 * * * \\
(0.176)\end{array}$ & $\begin{array}{c}0.261 * * * \\
(0.233)\end{array}$ & $\begin{array}{c}0.756 * * * \\
(0.203)\end{array}$ & $\begin{array}{c}0.446 * * * \\
(0.611)\end{array}$ & $\begin{array}{r}0.122 * * \\
(0.213)\end{array}$ \\
\hline
\end{tabular}




\begin{tabular}{lcccccccc} 
FDI & $0.175 * * *$ & $0.347 * * *$ & $0.398 * * *$ & $0.128 * * *$ & $0.363 * * *$ & $0.346 * * *$ & $0.246 * * *$ & $0.109 * * * *$ \\
& $(0.782)$ & $(0.213)$ & $(0.738)$ & $(0.986)$ & $(0.253)$ & $(0.273)$ & $(0.671)$ & $(0.342$ \\
INST & $0.122 * * *$ & $0.897 * * *$ & $0.636 * * *$ & $0.113 * * *$ & $0.288 * * *$ & $0.706 * * *$ & $0.346 * * *$ & $0.131 * * *$ \\
& $(0.042)$ & $(0.343)$ & $(0.783)$ & $(0.167)$ & $(0.334)$ & $(0.433)$ & $(0.931)$ & $(0.678)$ \\
Constant & $-0.090 * * *$ & $-0.071 * * *$ & 0.024 & $0.056 * * *$ & $0.039 * * *$ & $0.012 * * *$ & $0.022 * * *$ & $0.087 * * *$ \\
& $(0.464)$ & $(0.750)$ & $(0.022)$ & $(0.078)$ & $(0.012)$ & $(0.043)$ & $(0.032)$ & $(0.733)$ \\
& 640 & 640 & 640 & 640 & 640 & 640 & 555 & 640 \\
\hline
\end{tabular}

***, ** and * represent significance at the $1 \%, 5 \%$ and $10 \%$ level respectively. The dependent variable is GDP. ECI refers to eco NREN to non-renewable energy, OP to trade openness, FDI to foreign direct investment and INST to institutional quality. (2) Rob

Table 6: Powell (2015) fixed effect estimators' model

\begin{tabular}{|c|c|c|c|c|c|c|c|c|}
\hline & (1) & (2) & (3) & (4) & (5) & (6) & (7) & \\
\hline VARIABLES & 0.05 & 0.1 & 0.2 & 0.3 & 0.4 & 0.5 & 0.6 & \\
\hline \multirow{2}{*}{ ECI } & $0.340 * * *$ & $0.329 * * *$ & $0.103 * * *$ & $0.490 * *$ & $0.390^{*}$ & $0.578 * * *$ & $0.077 * * *$ & \\
\hline & $(0.306)$ & $(0.480)$ & $(0.471)$ & $(0.298)$ & $(0.280)$ & $(0.452)$ & $(0.103)$ & \\
\hline \multirow[t]{2}{*}{ REN } & $0.467 * * *$ & $0.302 * * *$ & $0.101 * * *$ & $0.389 * * *$ & $0.234 * * *$ & $0.453 * * *$ & $0.456^{* * *}$ & \\
\hline & $(0.022)$ & $(0.124)$ & $(0.091)$ & $(0.192)$ & $(0.104)$ & $(0.053)$ & $(0.030)$ & \\
\hline \multirow[t]{2}{*}{ NREN } & $-0.111 * * *$ & $-0.059 *$ & $-0.019 * * *$ & $0.098 * * *$ & $0.048 * * *$ & $-0.028 * * *$ & $0.152 * *$ & \\
\hline & $(0.451)$ & $(0.231)$ & $(0.038)$ & $(0.289)$ & $(0.059)$ & $(0.137)$ & $(0.114)$ & \\
\hline \multirow[t]{2}{*}{ OP } & $0.032 * * *$ & $0.107 * * *$ & $0.560 * * *$ & $0.477 * * *$ & $0.498 * * *$ & $0.346^{* * *}$ & $0.406^{* * *}$ & \\
\hline & $(0.122)$ & $(0.103)$ & (0.109) & $(0.266)$ & $(0.398)$ & $(0.103)$ & $(0.311)$ & \\
\hline \multirow[t]{2}{*}{ FDI } & $0.235^{* * *}$ & $0.527 * * *$ & $0.094 * * *$ & $0.289 * * *$ & $0.498 * * *$ & $0.376 * * *$ & $0.456 * * *$ & \\
\hline & $(0.432)$ & $(0.213)$ & $(0.392)$ & $(0.680)$ & $(0.386)$ & $(0.233)$ & $(0.201)$ & \\
\hline \multirow[t]{2}{*}{ INST } & $0.762 * * *$ & $0.107 * * *$ & $0.409 * * *$ & $0.289 * * *$ & $0.398 * * *$ & $0.736 * * *$ & $0.457 * * *$ & .2 \\
\hline & $(0.332)$ & $(0.549)$ & $(0.290)$ & $(0.238)$ & $(0.329)$ & $(0.474)$ & $(0.530)$ & \\
\hline \multirow[t]{2}{*}{ Constant } & $-0.056 * * *$ & $-0.044 * * *$ & $0.034 * *$ & $0.048 * * *$ & $0.077 * * *$ & $0.037 * * *$ & $0.065 * * *$ & $0 .($ \\
\hline & $(0.297)$ & $(0.950)$ & $(0.046)$ & $(0.086)$ & $(0.078)$ & $(0.033)$ & $(0.052)$ & \\
\hline Number of groups & 32 & 32 & 32 & 32 & 32 & 32 & 32 & \\
\hline
\end{tabular}

$* * *, * *$ and $*$ represent significance at the $1 \%, 5 \%$ and $10 \%$ level respectively. The dependent variable is GDP. ECI refers to econd to non-renewable energy, OP to trade openness, FDI to foreign direct investment and INST to institutional quality. (2) Robust stanc

Table 7: Powell (2016) fixed effect estimators' model

\begin{tabular}{|c|c|c|c|c|c|c|c|c|}
\hline & (1) & (2) & (3) & (4) & (5) & (6) & (7) & (8) \\
\hline VARIABLES & 0.05 & 0.1 & 0.2 & 0.3 & 0.4 & 0.5 & 0.6 & 0.7 \\
\hline ECI & $\begin{array}{c}0.760 \\
(0.102)\end{array}$ & $\begin{array}{c}0.460 * * * \\
(0.220)\end{array}$ & $\begin{array}{c}0.145 * * \\
(0.471)\end{array}$ & $\begin{array}{l}0.107 * \\
(0.058)\end{array}$ & $\begin{array}{c}0.456 * * * \\
(0.101)\end{array}$ & $\begin{array}{c}0.898 * * * \\
(0.892)\end{array}$ & $\begin{array}{c}0.101 * * * \\
(0.106)\end{array}$ & $\begin{array}{r}0.326 * * \\
(0.838)\end{array}$ \\
\hline REN & $\begin{array}{c}0.890 * * * \\
(0.189)\end{array}$ & $\begin{array}{c}0.338 * * * \\
(0.284)\end{array}$ & $\begin{array}{c}0.090 * * * \\
(0.021)\end{array}$ & $\begin{array}{c}0.082 * * * \\
(0.346)\end{array}$ & $\begin{array}{c}0.1222 * * * \\
(0.223)\end{array}$ & $\begin{array}{c}0.770 * * * \\
(0.663)\end{array}$ & $\begin{array}{c}0.789 * * * \\
(0.980)\end{array}$ & $\begin{array}{r}0.779 * * \\
(0.121)\end{array}$ \\
\hline NREN & $\begin{array}{c}-0.133 * * * \\
(0.281)\end{array}$ & $\begin{array}{c}-0.159 * * * \\
(0.201)\end{array}$ & $\begin{array}{c}-0.080 * * \\
(0.095)\end{array}$ & $\begin{array}{c}0.011 * * * \\
(0.674)\end{array}$ & $\begin{array}{c}0.049 * * * \\
(0.189)\end{array}$ & $\begin{array}{c}0.068 * * * \\
(0.337)\end{array}$ & $\begin{array}{c}-0.87 * * * \\
(0.774)\end{array}$ & $\begin{array}{r}-0.231 * \\
(0.569)\end{array}$ \\
\hline OP & $\begin{array}{c}0.038 * * * \\
(0.442)\end{array}$ & $\begin{array}{c}0.477 * * * \\
(0.263)\end{array}$ & $\begin{array}{c}0.634 * * * \\
(0.681)\end{array}$ & $\begin{array}{c}0.054 * * * \\
(0.076)\end{array}$ & $\begin{array}{l}0.333 * \\
(0.209)\end{array}$ & $\begin{array}{c}0.886 \\
(0.223)\end{array}$ & $\begin{array}{c}0.036 * * * \\
(0.211)\end{array}$ & $\begin{array}{r}0.092 * * \\
(0.383)\end{array}$ \\
\hline FDI & $0.285 * * *$ & $0.227 * * *$ & $0.128 * * *$ & $0.238 * * *$ & $0.074 * * *$ & $0.102 * * *$ & $0.096 * * *$ & $0.389 *$ \\
\hline
\end{tabular}




\begin{tabular}{|c|c|c|c|c|c|c|c|c|}
\hline & $(0.282)$ & $(0.983)$ & $(0.538)$ & $(0.086)$ & $(0.223)$ & $(0.433)$ & $(0.121)$ & $(0.212$ \\
\hline \multirow[t]{2}{*}{ INS } & $0.032 * * *$ & $0.127 * * *$ & $0.236 * * *$ & $0.123 * * *$ & $0.222 * * *$ & $0.103 * * *$ & $0.298 * * *$ & $0.001 * * *$ \\
\hline & $(0.122)$ & $(0.233)$ & $(0.183)$ & $(0.057)$ & $(0.124)$ & $(0.122)$ & $(0.221)$ & $(0.128)$ \\
\hline \multirow[t]{2}{*}{ Constant } & $-0.030 * * *$ & $-0.431 * * *$ & $0.004 * *$ & $0.036 * * *$ & $0.087 * * *$ & $0.023 * * *$ & $0.099 * * *$ & $0.047 * * *$ \\
\hline & (0.089) & $(0.293)$ & $(0.086)$ & (0.334) & $(0.056)$ & $(0.008)$ & $(0.092)$ & $(0.113)$ \\
\hline Observations & 640 & 640 & 640 & 640 & 640 & 640 & 555 & 640 \\
\hline
\end{tabular}

The first panel data quantile model with fixed effects was proposed by Canay $(2011)^{3}$ (Table 5), and the improved generalized method of quantile panel data estimation was then developed by Powell (2016) and Graham et al. (2018) (Table 6). The panel quantile estimator developed by Graham et al. (2018) is a special case of the generalized quantile estimation implemented by Powell (2016), and addresses a fundamental problem posed by alternative fixed-effects quantile estimators. Specifically, the inclusion of fixed effects alters the interpretation of the estimation coefficient on the treatment variable, and is known in the literature as the Powell (2015) method, although an important contribution was made by Graham et al. (2018). Powell (2016) developed the generalized quantile estimator to address a fundamental problem in traditional quantile estimators, namely that the inclusion of additional covariates alters the interpretation of the estimated coefficient on the treatment variable (Table 7). The generalized quantile estimator resolves all these issues and produces unconditional quantile treatment effects even in the presence of additional control variables, while also allowing for endogeneity and the inclusion of additional instruments and additional "proneness" variables. However, Powell's estimation approach (2015), which is a special case of the generalized quantile estimation, addresses a fundamental problem of alternative fixed-effect quantile estimators, namely that the inclusion of fixed effects alters the interpretation of the estimated coefficient on the treatment variable.

\footnotetext{
${ }^{3}$ The coverage is very close to the nominal level when $\mathrm{T}=20$, and below the nominal level for $\mathrm{T}=5$. It is worth noting that the coverage can be expected to deteriorate in two circumstances. Given a value of $n$, a smaller $\mathrm{T}$ implies a larger finite sample bias and hence a finite sample distribution centred further from the truth. Given a value of T, a larger value of $n$ keeps the finite sample bias unaffected but implies a finite sample distribution that is mostly concentrated around the wrong place. However, even for a case with $12 \%$ bias (model $1, \mathrm{~T}=5$ ), the actual coverage levels are about $85 \%$, which is quite acceptable for such small values of T and a bias over 10\% (see Canay (2011) for details).
} 


\section{5.- Conclusion \& Policy Implications.}

In order to honour the COP21 and comply with the objective of maintaining stable economic growth, this paper analyses the scope of both renewable and non-renewable energy consumption for growth in 32 European economies. The Paris Agreement (COP21) establishes a framework in which nations, including all European nations, are expected to play a proactive part in tackling climate change, requiring them to base their economic activity and growth on more sustainable sources. We also explore the link between energy consumption (nonrenewable and renewable) and economic growth by exploring the implications of economic complexity, trade openness, FDI and institutional quality in the selected European economies using a panel quantile regression approach. Our key findings lead us to conclude that economic complexity (ECI) has a favourable impact on growth, thereby increasing growth in the underlying European economies. The fact that ECI has a greater impact on GDP than trade openness suggests that countries should focus on long-term policies and strategies to enhance innovation in goods and services. The positive effects of complexity point to its importance and sophistication in European economies. This study confirms that complexity increases the ability to adapt sustainable economic systems and reduce environmental pressure, and highlights the need to drive economic systems along the path towards a green economy in order to fulfil environmental agreements such as COP21. Renewable energy consumption (REN) showed the most significant and positive effects on the growth of the underlying economies, proving that it supports growth in the selected European economies and can therefore lead to a win-win situation. This suggests that in terms of energy policy, renewable energy consumption should be encouraged by policymakers in order to achieve sustainable growth and comply with the Paris agreement. The positive results in all quantiles strongly support the notion that investing in renewables is the best policy. Interestingly, the analysis of non-renewable energy showed less promising results for economic growth than renewable energy. The coefficients for nonrenewable energy have both statistically significant negative and positive signs in some 
quantiles, offering further insight into the underlying economies; however, these contrasting results also show that countries make inefficient use of non-renewable energy sources. The main reason for the negative signs may be that the country directs its energy consumption to inefficient sectors. The more promising results for the consumption of renewable rather than non-renewable energy in regard to enhancing economic growth demonstrate that renewable energy is more useful for sustainable growth. The economies in question should therefore concentrate their energy policies and strategies on renewable energy, which provides optimal results for sustainable economic growth.

The results confirm that trade openness has positive effects on growth, which are also statistically significant in all quantiles. This is unsurprising, as there is a positive association between these two factors. However, our findings contribute to and contradict studies suggesting that trade openness plays only a minor role in enhancing economic growth, or that trade tariffs and related taxes have a direct association with economic growth. In the policy context, this would imply that it is crucial to enhance trade to ensure economic growth in the underlying economies. However, FDI and institutional quality had a very strong positive and statistically very significant impact on economic growth, implying that economic and public policy should focus on improving institutional quality and attracting FDI inflows.

The findings presented in this study are statistically highly significant and also contradict the notion of a weak association between energy consumption, economic complexity, trade, FDI and institutional quality, and economic growth. The empirical results are intuitive, as these factors can be expected to benefit countries in multiple ways. For example, while energy is an important ingredient of economic activity, transfer for production occurs through international trade, which allows countries to increase their output. Overall, it can be inferred that the complexity and sophistication of the economy, renewable energy consumption and trade enhance economic growth. The mixed results with regard to the consumption of non-renewable 
energy points to the need to focus investment more closely on the renewable energy sector to ensure sustainable growth and honour the commitments made by European nations in the Paris Agreement. Our research has some limitations and its scope can be extended to include the environmental degradation caused by growth. The key question requiring further enquiry is how the growth resulting from economic complexity, energy consumption, institutional quality, FDI and trade affects the environment and Europe's commitment to the COP21. The study can also be extended to non-European nations. 


\section{References}

Abosedra, S.S., Baghestani, H., 1991. New evidence on the causal relationship between United States energy consumption and gross national product. J. Energy Dev. 14(2), 285-292.

Adhikary, B.K., 2011. FDI, trade openness, capital formation, and economic growth in Bangladesh: a linkage analysis. Int. J. Bus. Manag. 6(1), 16-28.

Agosin, M.R., 2009. Export diversification and growth in emerging economies. CEPAL Rev. (97), 115-131.

Ahmed, S., Sattar, Z., 2004. Trade liberalisation, growth, and poverty reduction: the case of Bangladesh. World Bank Working Paper 34204, 1-46.

Altunbaş, Y., Thornton, J., 2019. The impact of financial development on income inequality: A quantile regression approach. Econ. Lett. 175, 51-56.

Álvarez, A., Balsalobre, D., Cantos, J.M., Shahbaz, M., 2017. Energy innovations-GHG emissions nexus: Fresh empirical evidence from OECD countries. Energy Policy 101, 90100.

Andersson, F.N.G., Opper, S., Khalid, U., 2018. Are capitalists green? Firm ownership and provincial $\mathrm{CO}_{2}$ emissions in China. Energy Policy 123, 349-359.

Antonelli, C., 2016. Technological congruence and the economic complexity of technological change. Struct. Chang. Econ. Dyn. 38, 15-24.

Apergis, N., Can, M., Gözgör, G. Lau, C.K.M., 2018. Effects of export concentration on $\mathrm{CO}_{2}$ emissions in developed countries: an empirical analysis. Environ. Sci. Pollut. Res. 25(14), 14106-14116.

Apergis, N., Payne, J.E., 2010. Renewable energy consumption and growth in Eurasia. Energy Econ. 32, 1392-1397.

Apergis, N., Payne, J.E., 2012. Renewable and Non-Renewable Energy Consumption Growth Nexus: Evidence from a Panel Error Correction Model. Energy Econ. 34, 733-738.

Azlina, A.A., Law, S.H., Mustapha, N.H.N., 2014. Dynamic linkages among transport energy consumption, income, and $\mathrm{CO}_{2}$ emission in Malaysia. Energy Policy 73, 598-606.

Babatunde, A., 2011. Trade openness, infrastructure, FDI and growth in Sub-Saharan African countries. J. Manag. Policy Pract, 12(7), 27-36.

Baker, M., 2016. GENQREG: Stata module to perform Generalized Quantile Regression. Statistical Software Components, 458158, Boston College Department of Economics.

Bale, C.S.E., Varga, L., Foxon, T.J., 2015. Energy and complexity: New ways forward. Appl. Energy 138, 150-159.

Balsalobre, D., Álvarez, A., Cantos, J.M., 2015. Public budgets for energy RD\&D and the effects on energy intensity and pollution levels. Environ. Sci. Pollut. Res. 22(7), 4881.

Baltagi, B.H., Feng, Q., Kao, C., 2012. A Lagrange Multiplier test for cross-sectional dependence in a fixed effects panel data model. J. Econom. 170(1), 164-177.

Bowden, N., Payne, J.E., 2009. The causal relationship between U.S. energy consumption and real output, a disaggregated analysis. J. Policy Model. 31(2), 180-188.

Bowden, N., Payne, J.E., 2010. Sectoral analysis of the causal relationship between renewable and non-renewable energy consumption and real output in the US, energy sources, part B: economics. Plan. Policy 5(4), 400-408. 
Breusch, T., Pagan, A., 1980. The Lagrange multiplier test and its application to model specification in econometrics. Rev. Econ. Stud. 47, 239-254.

Bustos, P., Caprettini, B., Ponticelli, J., 2016. Agricultural productivity and structural transformation: evidence from Brazil. Am. Econ. Rev. 106(6), 1320-1365.

Cadoret, I., Padovano, F., 2016. The political drivers of renewable energies policies. Energy Econ. 56, 261-269.

Can, M., Gozgor, G., 2017. The impact of economic complexity on carbon emission: Evidence from France. Environ. Sci. Pollut. Res. 24, 6364-16370.

Canay, I.A., 2011. A simple approach to quantile regression for panel data. Econom. J. 14(3), 368-386.

Carlin, W., Glyn, A., Van Reenen, J., 2001. Export Market Performance of OECD Countries: An Empirical Examination of the Role of Cost Competitiveness. Econ. J. 111 (1), 128-162.

Chang, C., Mendy, M., 2012. Economic growth and openness in Africa: what is the empirical relationship? Appl. Econ. Lett. 19(18), 1903-1907.

Chen, J., Zhou, C., Wang, S., Li, S., 2018. Impacts of energy consumption structure, energy intensity, economic growth, urbanization on PM2.5 concentrations in countries globally. Appl. Energy 230, 94-105.

Chunbo, M., David, I., 2008. China's changing energy intensity trend: A decomposition analysis. Energy Econ. 30, 1037-1053.

Clémençon, R., 2016. The two sides of the Paris climate agreement: dismal failure or historic breakthrough. J. Environ. Dev. 25 (1), 3-24.

Constant, N.B.Z.S., Yaoxing, Y., 2010. The relationship between foreign direct investment, trade openness and growth in Cote d'Ivoire. Int. J. Bus. Manag. 5(7), 99-107.

Dhrifi, A., Jaziri, R., Alnahdi, S., 2019. Does foreign direct investment and environmental degradation matter for poverty? Evidence from developing countries. Struct. Chang. Econ. Dyn. 52, 13-21.

Doğan, B., Saboori, B., Can, M. 2019. Does economic complexity matter for environmental degradation? An empirical analysis for different stages of development. Environ. Sci. Pollut. Res. 26, 31900-31912.

Eagle, N., Macy, M., Claxton, R., 2010. Network diversity and economic development. Science 328 (5981), 1029-1031.

Edwards, S., 1998. Openness, productivity, and growth: What do we really know? Econ. J. 108, 383-398.

Eris, MN., Ulasan, B., 2013. Trade openness and economic growth: Bayesian model averaging estimate of cross-country growth regressions. Econ. Model. 33, 867-883.

Erkan, B., Kaya, E., 2015. Economic Complexity and Export Competitiveness: The Case of Turkey. Procedia Environ. Sci. Eng. Manag. 195, 524-533.

Erkan, B., Yildirimci, E., 2015. Economic Complexity and Export Competitiveness: The Case of Turkey. Procedia Environ. Sci. Eng. Manag. 195, 524-533.

Ewing, B.T., Sari, R., Soytas, U., 2007. Disaggregate energy consumption and industrial output in the United States. Energy Policy 35(2), 1274-1281. 
Fallahi, F., 2011. Causal relationship between energy consumption (EC) and GDP, a Markovswitching (MS) causality. Energy 36(7), 4165-4170.

Fang, X., Misra S., Xue G., Yang D., 2012. Smart grid-The new and improved Power grid: A survey. IEEE Commun. Surv. Tutor. 14(4), 944-980.

Fang, Y., 2011. Economic welfare impacts from renewable energy consumption, the China experience. Renew. Sustain. Energy Rev. 15(9), 5120-5128.

Feng, T.W., Sun, L.Y., Zhang, Y., 2009. The relationship between energy consumption structure, economic structure, and energy intensity in China. Energy Policy 37, 5475-5483.

Ferrarini, B., Scaramozzino, P., 2016. Production complexity, adaptability, and economic growth. Struct. Chang. Econ. Dyn. 37, 52-61.

Gala, P., 2017. Complexidade Econômica: uma nova perspectiva para entender a antiga questão da riqueza das nações. Eds. Contraponto, Rio de Janeiro.

Galvao, A.F., 2011. Quantile regression for dynamic panel data with fixed effects. J. Econom. 164(1), 142-157.

Gao, J., Zhou, T., 2016. Big data reveal the status of economic development. J. Electron. Sci. Technol. 45, 625-633.

Gozgor, G., 2018. A new approach to the renewable energy-growth nexus, evidence from the USA. Environ. Sci. Pollut. Res. 25 (17), 16590-16600.

Graham, B. S., Hahn, J., Poirier, A., Powell, J.L., 2018. A quantile correlated random coefficients panel data model. J. Econom. 206(2), 305-335.

Hajko, V., Sebri, M., Al-Saidi, M., Balsalobre-Lorente, D., 2018. The energy-growth nexus: history, development, and new challenges. In The economics and econometrics of the energy-growth nexus. Academic Press. pp. 1-46.

Harrison, A., 1996. Openness and growth. A time-series, cross-country analysis for developing countries. J. Dev. Econ. 48(2), 419-447.

Hartmann, D., 2014. Economic complexity and human development: how economic diversification and social networks affect human agency and welfare. 110. Eds. Routledge, New York.

Hartmann, D., Guevara, M., Jara-Figueroa, C., Aristarán, M., Hidalgo, C., 2017. Linking economic complexity, institutions, and income inequality. World Dev. 93, 75-93.

Hartmann, D., Jara-Figueroa, C., Guevara, M., Simoes, A., Hidalgo, C.A., 2016. The structural constraints of income inequality in Latin America. Int. Trade J. 40, 70-85.

Hausmann, R, Hidalgo, C.A., Bustos, S., Coscia, M., Chung, S., Jimenez, J., Simoes, A., Yildirim, M., 2011. The atlas of economic complexity. Eds. Puritan Press, Cambridge MIT Press.

Hausmann, R., Hwang, J., Rodrik, D., 2007. What you export matters. J. Econ. Growth 12 (1), $1-25$.

Hausmann, R., Klinger, B., 2006. Structural transformation and patterns of comparative advantage in the product pace. CID Working Paper 128. Kennedy School of Government, Harvard University.

Hayat, A., 2019. Foreign direct investments, institutional quality, and economic growth. The J. Int. Trade Econ. Dev. 28(5), 561-579. 
Hesse, H., 2009. Economic growth and diversification. In, (eds) Newfarmer, R., Shaw, W., Walkenhorst, P., Breaking into new markets, p. 55-80.

Hidalgo, C., 2015. Why Information Grows: The Evolution of Order, from Atoms to Economies. Eds. Penguin Press, New York.

Hidalgo, C.A., Hausmann, R., 2009. The building blocks of economic complexity. Proc. Natl. Acad. Sci. U.S.A. 106(26), 10570-10575.

Hidalgo, C.A., Klinger, B., Barabasi, A.L., Hausmann, R., 2007. The product space conditions the development of nations. Science 317(5837), 482-487.

Hoechle, D., 2007. Robust standard errors for panel regressions with cross-sectional dependence. Stata J. 7(3), 281-312.

Hu, Y., Peng, L., Li, X., Yao, X., Lin, H., Chi, T., 2018. A novel evolution tree for analysing the global energy consumption structure. Energy 147, 1177-1187.

Huchet-Bourdon, M., Le Mouël, C., Vijil, M., 2017. The relationship between trade openness and economic growth: Some new insights on the openness measurement issue. World Econ. 41 (1), 59-76.

ICRG., 2019. International Country Risk Guide (ICRG) Researchers Dataset. [Online] Available at: https://dataverse.harvard.edu/dataset.xhtml?persistentId=hdl:1902.1/21446 [accessed 20 April 2020].

IMF., 2017. International Monetary Fund: Fostering Inclusive Growth: G-20 leaders' summit. Hamburg: IMF. Retrieved in 2017, September 15.

Jalil, A. Feridun, M., 2014. Energy-driven economic growth: Energy consumption-economic growth nexus revisited for China. J. Emerg. Mark. Finance 50(5), 159-168.

Karras, G., 2003. Trade openness and economic growth: can we estimate the precise effect? Appl. Econ. Int. Dev. 3(1), 7-25.

Kinley, R., 2017. Climate change after Paris: from turning point to transformation. Clim. Policy 17 (1), 9-15.

Klinger, B., Lederman, D., 2006. Diversification, innovation, and imitation inside the Global Technological Frontier. World Bank Policy Research Working Paper (3872).

Koenker, R., 2004. Quantile regression for longitudinal data. J. Multivar. Anal. 91 (1), 74-89.

Kraft, J. Kraft, A., 1978. On the relationship between energy and GNP. J. Energy Dev. 3(2), 401-403.

Krugman, P.R., 1987. Is free trade passé? J. Econ. Perspect. 1(2), 131-144.

Lapatinas, A., Garas, A., Boleti, E., Kyriakou, A., 2019. Economic complexity and environmental performance: Evidence from a world sample. Online at https://mpra.ub.unimuenchen.de/92833/MPRA No. 92833.

Lee, J.W., 2016a. Korea's economic growth and catch-up: implications for China. China and World Econ. 24(5), 71-97.

Lee, J.W., 2016b. China's economic growth and convergence. CAMA Working Paper, (30), 154.

Lin, J.Y., Wang, Y., 2015. Catching up: structural transformation and diversification. In development and modern industrial policy in practice. Eds. Edward Elgar Publishing. 
Mariano, E.B., Rebelatto, D.A.D., 2014. Transformation of wealth produced into quality of life: analysis of the social efficiency of nation-states with the DEA's triple index approach. J. Oper. Res. Soc. 65(11), 1664-1681.

Muradov, N., 2014. Liberating energy from carbon: introduction to decarbonization. Eds. Springer Science., New York

Mustafa, G., Rizov, M., Kernohan, D., 2017. Growth, human development, and trade: the Asian experience. Econ. Model. 61, 93-101.

Mutoh, N., Ohno, M, Inoue, T., 2006. A method for MPPT control while searching parameters corresponding to weather conditions for PV generation systems. IEEE Trans. Ind. Electron. $53,1055-1065$.

Myrdal, G., 1957. Economic Theory and Underdeveloped Regions. Eds. Gerald Druckworth.

Nkurunziza, J.D., Tsowou, K., Cazzaniga, S., 2017. Commodity Dependence and Human Development. Afr. Dev. Rev. 29(S1), 27-41.

Ocal, O., Aslan, A., 2013. Renewable energy consumption-economic growth nexus in Turkey. Renew. Sust. Energ. Rev. 28, 494-499.

Pao, H.T., Fu, H.C., 2013. Renewable energy, non-renewable energy, and economic growth in Brazil. Renew. Sust. Energ. Rev. 25, 381-392.

Payne, J.E., 2009. On the dynamics of energy consumption and output in the US. Appl. Energy $86,575-577$.

Pesaran, M.H., 2004. General Diagnostic Tests for Cross Section Dependence in Panels, University of Cambridge Working Paper, 0435.

Powell, D., 2015. Quantile Regression with Nonadditive Fixed Effects. Quantile Treatment Effects. Available at: http://works. bepress.com/david_powell/1/

Powell, D., 2016. Quantile regression with non-additive fixed effects. RAND working paper. http://works.Bepress.com/david_powell/1/

Rao, B.B., Rao, M., 2009. Openness and growth in Fiji: some time series evidence. Appl. Econ. $41,1653-1662$.

Redmond, T., Nasir, M.A., 2020. Role of natural resource abundance, international trade, and financial development in the economic development of selected countries. Resour. Policy 66, 101591.

Romer, P.M., 1990. Endogenous technological change. J. Polit. Econ. 98(5), 71-102.

Rosenstein-Rodan, P.N., 1943. Problems of industrialisation of eastern and south-eastern Europe. Econ. J. 53, 202-211.

Rostow, W.W., 1959. The stages of economic growth. Econ. Hist. Rev. 12(1), 1-16.

Rostow, W.W., 1990. The stages of economic growth: A non-communist manifesto. Eds. Cambridge university press.

Sachs, I., 2004. Desenvolvimento includente, sustentável, sustentado. Eds. Garamond, Rio de Janeiro.

Saviotti, P.P., Pyka, A., 2004. Economic development by the creation of new sectors. J. Evol. Econ. 14(1), 1-35.

Saviotti, P.P., Pyka, A., 2013. From necessities to imaginary worlds: structural change, product quality and economic development. Technol. Forecast Soc. Change 80(8), 1499-1512. 
Saviotti, PP., Pyka, A., Jun, B., 2016. Education, structural change, and economic development. Struct. Chang. Econ. Dyn. 38, 55-68.

Saygin, D., Kempener, R., Wagner, N., Ayuso, M., Gielen, D., 2015. The Implications for Renewable Energy Innovation of Doubling the Share of Renewables in the Global Energy Mix between 2010 and 2030. Energies 8, 5828-5865

Schwartz, B., 2004. The Paradox of Choice. Why more is less. Eds. Harper Collins Publisher, New York.

Sen, A., 1981. Public action and the quality of life in developing countries. Oxf. Bull. Econ. Stat. 43(4), 287-319.

Sen, A., 1998. Mortality as an indicator of economic success and failure. Econ. J. 108(446), 125.

Sen, A., 2001. Development as freedom. Eds. Oxford Paperbacks, Oxford.

Shahbaz, M., Shafiullah, M., Khalid, U., Song, M., 2020. A nonparametric analysis of energy environmental Kuznets Curve in Chinese Provinces. Energy Econ., In press.

Shahbaz, M., Shafiullah, M., Mahalik, M.K., 2019. The dynamics of financial development, globalisation, economic growth, and life expectancy in sub-Saharan Africa. Aust. Econ. Pap. 58(4), 444-479.

Shahbaz, M., Shafiullah, M., Papavassiliou, V.G. Hammoudeh, S., 2017. The $\mathrm{CO}_{2}$-growth nexus revisited: A nonparametric analysis for the $\mathrm{G} 7$ economies over nearly two centuries. Energy Econ. 65, 183-193.

Sovacool, B., Brown, M., 2009. Scaling the Policy Response to Climate Change. Policy Soc. 27(4), 317-328.

Soytas, U., Sari, R. Ewing, B.T., 2007. Energy consumption, income, and carbon emissions in the United States. Ecol. Econ. 62(3-4), 482-489.

Stafforte, S., Tamberi, M., 2012. Italy in the space (of products). Economia Marche. J. Appl. Econ. 31(1), 90-113.

Suri, T., Boozer, M.A., Ranis, G., Stewart, F., 2011. Paths to success: the relationship between human development and economic growth. World Dev. 39(4), 506-522.

Tacchella, A., Cristelli, M., Caldarelli, G., Gabrielli, A., Pietronero, L., 2013. Economic complexity: conceptual grounding of a new metrics for global competitiveness. J. Econ. Dyn. Control 37(8), 1683-1691.

Tiwari, A.K., 2014. The asymmetric Granger-causality analysis between energy consumption and income in the United States. Renew. Sustain. Energy Rev. 36, 362-369.

UNDP., 2000. United Nations Development Programme: The Human Development Report 2000. Eds. Oxford University Press, New York.

Vandyck, T., Keramidas, K., Saveyn, B., Kitous, A., Vrontisi, Z., 2016. A global stocktake of the Paris pledges: implications for energy systems and economy. Global Environmental Change 41, 46-63.

Yan, Q., Yin, J., Balezentis, T., Makuteniene, D., Streimikiene, D., 2017. Energy-related GHG emission in agriculture of the European countries: An application of the Generalized Divisia Index. J. Clean. Prod. 164, 686-694. 
Yanıkkaya, H., 2003. Trade openness and economic growth: A cross-country empirical investigation. J. Dev. Econ. 72, 57-89.

Yildirim, E., Saraç, S., Aslan, A., 2012. Energy consumption and economic growth in the USA: Evidence from renewable energy. Renew. Sust. Energ. Rev. 16(9), 6770-6774.

Yin, J., Zheng, M., Chen, J., 2015. The effects of environmental regulation and technical progress on $\mathrm{CO}_{2}$ Kuznets curve: An evidence from China. Energy Policy 77, 97-108.

Zahonogo, P., 2017. Trade and economic growth in developing countries: evidence from SubSaharan Africa. J. Afr. Trade 3(1-2), 41-56.

Zhang, M., Song, Y., 2015. Exploring influence factors governing the changes in China's final energy consumption under a new framework. Nat. Hazards 78, 653-668.

Zheng, H., Hu, J., Wang, S., Wang, H., 2019. Examining the influencing factors of $\mathrm{CO}_{2}$ emissions at city level via panel quantile regression: evidence from 102 Chinese cities. Appl. Econ. 51(35), 3906-3919. 